\title{
VERBALISME BAHASA ARAB \\ DALAM KEHIDUPAN BERAGAMA MASYARAKAT MUSLIM
}

\author{
Inchinia Angger Rowin \\ Dosen Sekolah Tinggi Agama Islam Hasanuddin Pare Kediri \\ Email: inchiniaar@gmail.com
}

\begin{abstract}
Religious life and language have a very close relationship that affects the lives of the people. The role of language in religious studies is very important for its adherents, so that when they read religious texts or listen to their appeals they can make them understand the content and purpose of the text. For the Muslim community the Arabic language becomes a major that they must master and understand because the original sources of Islamic teachings and sciences are Arabic, so it is very important for Muslims especially their scientists to learn, understand, and master the Arabic language. Otherwise, it is difficult for us to study Islam from its original source derived from Arabic. However, this is the most special problem in Islamic societies. As a result of unwell understanding Arabic, unfortunately religion becomes easy to sell, religion is easily diverted, religion brought by unscrupulous person in deviation path, religion used as media for certain purposes. Arabic verbalism has happened in Muslim society in Indonesia, they make A rabic as formality, only just a form. So there is no inner or deep value inside of it. It is necessary to reform efforts in its wrong ideology, including changing the culture of verbalism in society, to put the position of Arabic language not only to memorize but used as a tool in deepening knowledge, one of the science of religion.
\end{abstract}

Keywords: Verbalism, Arabic Language, Religious Life

Nazhruna: Jurnal Pendidikan Islam

Vol. 1 No 1 Maret 2018. Issn: 2614-8013. Hal. 20-36 


\section{Pendahuluan}

Citra dan wibawa bahasa dan keilmuan bahasa akan selalu di perbincangkan ketika masih ada manusia yang menatap peradabannya dengan mempertautkan teks-konteks kehidupan. Sudah sejak awal ketika manusia pertama diciptakan (Adam) dan diturunkan ke dunia, bahasa sudah dengan sengaja tidak dapat dilepaskan dari manusia. bahasa juga menjadi cara dasar manusia memahami alam dan dirinya.

Bahasa merupakan suatu sistem simbol yang memiliki makna, dan makna adalah arti yang mengacu pada suatu fakta dan realita. Artinya, tidak akan terwujud suatu bahasa yang hanya merupakan serangkaian bunyi yang tidak bermakna. Karena bermakna itulah maka sistem simbol itu sendiri disebut bahasa. Bahasa menjadi tema sentral di mana dimensi-dimensi bahasa tampil dalam bentuk penilaian, pernyataan, representasi, pergeseran pemikiran, juga dalam sifat kontekstual dan pragmatisnya. Baik dalam persoalan kontradiksi yang bersifat deskriptif-logis atau pluralitas permainan bahasa.

Pada hakikatnya, bahasa merupakan media untuk menuangkan ide sekaligus menyampaikan pesan tertentu kepada orang lain.Ide-ide tersebut bersumber dari intuisi, imaji dan pengalaman pribadi seorang pemakai bahasa. Bahasa punya hakikat memengaruhi, menyampaikan sesuatu, menguasai, menakhlukkan dan menundukkan pelbagai ihwal ke dalam suatu universalisme. Melalui bahasa pula seseorang berpikir tentang kemungkinan-kemungkinan, kualitas, hubungan, nilai dan sebagainya sehingga bahasa dapat dilihat sebagai cara kita mengalami dan memahami kenyataan dan cara kenyataan tampil kepada kita1.

Tidak dapat dipungkiri bahwa bahasa memegang peranan penting dan strategis dalam hubungan dan fungsinya dengan kegiatan informasi dan transformasi. Dalam kenyataannya bahasa tidak dapat dianggap sebagai ruang hampa. Bahasa merupakan seni verbal sebagai inti semiotika kemanusiaan yang merupakan aktivitas yang bermakna dalam komunitasnya, bahasa merupakan kode-kode yang memiliki fungsi beraneka ragam.

1 Fathul Mujib, 'Rekonstruksi Pendidikan Bahasa Arab', Yogyakarta: Pedagogia, 2010, 2-3. 
Berangkat dari sebuah kerangka pikir tentang pentingnya bahasa dalam kehidupan manusia, tentunya hubungan bahasa dan kehidupan beragama juga memiliki hubungan yang sangat erat dan sering pula mesra sifatnya. Diketahui bahwasanya jumlah agama-agama besar tidak banyak di dunia. Karena itu, bahasa yang menjadi media kitab suci juga tidak banyak. Adapun naskah-naskah kitab suci ini dirasakan lebih agung dan syahdu sifatnya bila tertulis dalam bahasa aslinya, jadi bukan dalam bentuk terjemahan. Seperti naskah kitab suci agama Islam yang berbahasa Arab, agama Katolik berbahasa Latin, dan seterusnya.

Perlu banyak kita ketahui bahwasanya dalam kehidupan beragama terlihat peristiwa pemakaian bahasa yang agak berbeda dari pemakaian bahasa di bidang lain. Dalam masyarakat agama juga terdapat pandangan: "Makin tidak dipahami apa yang didengar, makin hormat dan kagum orang kepada bahasa apa yang didengar dan kepada pengungkapnya”. Seperti orang Katolik ketika melakukan pembacaan ritual doa dalam bahasa Latin, maka doa tersebut dianggap luar biasa. Demikian juga umat Islam yag memiliki pandangan bacaan doa dikatakan afdal jika dibaca dengan bahasa Arab. Upacara dan ritual keagamaan dirasakan lebih khidmat bila dilakukan dalam bahasa tertentu daripada bahasa lain.

Islam adalah agama yang identik dengan bahasa Arab. Asumsi yang selama ini berkembang adalah bahwa bahasa Arab adalah bahasa agama Islam. Pendapat ini tak perlu disalahkan atau diperdebatkan. Sebab, keseluruhan ajaran Islam terdapat dalam Al-Qur'an dan hadis Nabi yang berbahasa Arab. Bahasa Arab juga diklaim sebagai "bahasa Tuhan” (mengandung unsur keilahian) karena Al-Qur'an merupakan kalam Tuhan (kalamullah), berupa bahasa Arab yang terbukukan. Dan juga al-Qur'an adalah kitab suci umat Islam yang mempunyai nilai I'jaz yang abadi dari berbagai aspeknya, naik tasyri'iy, lughawiy, maupun 'ilmy.2 Penghadiran bahasa Arab tersebut kemudian mengalami proses sejarah. Dalam pengembangannya juga memengaruhi karakter dan

2 Al-Qattan Manna, Mababis Fi 'Ulumi-Qur'an, 4th ed. (Riyad: Mansyurat alAsr al-Hadis, 2005), 264. 
pola pikir, watak, kultur, dan intelektualitas,serta bahasa masyarakat di dunia.

Namun, tanpa disadari ini menjadi problem masyarakat muslim, verbalisme telah terjadi dalam masyarakat muslim di Indonesia. Mereka membaca doa berbahasa Arab tetapi tidak tahu maknanya, melafalkan bacaan dalam gerakan ritual ibadah tetapi tidak tahu maknanya, rutin membaca dan mendengarkan bacaan ayat suci AlQur'an tetapi tidak memahami arti maksudnya. Ini semua diakibatkan oleh praktek verbalisme pada bahasa Arab yang menyebabkan kurangnya pengetahuan dan penghayatan pada arti agama dan fungsi agama itu sendiri.

\section{Hubungan Bahasa Dan Agama}

Bahasa adalah alat komunikasi antara anggota masyarakat berupa simbol bunyi yang dihasilkan oleh alat ucap manusia. Ketika anggota masyarakat menginginkan untuk berkomunikasi dengan sesamanya, maka orang tersebut akan menggunakan suatu bahasa yang sudah biasa digunakannya untuk menyampaikan sesuatu informasi3.

Bahasa bersifat dinamis, tumbuh dan berkembang sejalan dengan meningkatnya kemajemukan persepsi manusia terhadap makrokosmos dan mikrokosmos.4 Oleh karena itu makna sebuah leksem kadang-kadang mengalami perubahan (baik dari makna sempit menjadi luas atau sebaliknya, bahkan hilang maknanya atau berubah sama sekali) dan kadang-kadang tetap5.

Pada dasarnya manusia adalah makhluk sosial yang saling berinteraksi antara satu dengan yang lain, agar komunikasi diantara mereka berjalan dengan baik dan lancar dibutuhkan sarana yang mampu menjembatani keinginan dan maksud yang akan disampaikan,

\footnotetext{
3 Gorys Keraf, Komposisi: sebuah pengantar kemahiran bahasa (Ende, Flores: Nusa Indah, 2001),
http://catalog.hathitrust.org/api/volumes/oclc/66969327.html. 106.

4 Aminuddin, Pengantar Studi Tentang Makna (Bandung: Sinar Baru, 1988),

5 Hilal Abdul Gaffar Hamid, Imu Lughah Bainal-Qadim wal-Hadist (Cairo: Dar al-Kotob Al-Ilmiyah, 1986), 195.
} 
dalam hal ini media komunikasi yang paling berpengaruh dalam kehidupan manusia adalah bahasa6.

Bahasa umat manusia adalah bahasa lisan (linguistik), menurut Zulkarnain dikarenakan semua orang di dunia sebelum bisa menulis sudah bisa berbicara, walaupun masih buta huruf dan terbelakang, misalnya suku Kubu, Mentawai, Badui dan lain-lainnya. Hal ini berarti bahasa lisan merupakan gambaran yang paling sempurna, karena pada bahasa tersebut terdapat mimic, tekanan, jungture, prosadi dan lainlainnya7. Bahasa lisan memang sangat perperan dalam intraksi keseharian umat manusia, namun dia tidak dapat memberikan peran besarnya itu tanpa bahasa tulisan. Kitab suci, hadits, fiqih, aqidah, filsafat dan lain-lainnya tidak akan sampai kepada kita secara utuh kalau tidak ada bahasa tulisan.

Dalam kehidupan sehari-hari kitamenjumpai gosip, hinaan, sindiran, ejekan, kritik, bantahan dan pujian. Kita juga menjumpai peresmian gedung, deklarasi partai, pembukaan sidang, pelantikan pejabat, keputusan presiden, diagnosis dokter,publikasi ilmiah, akad pernikahan, perjanjian jual beli, hingga vonis hukum. Semua diskursus ini, hingga tingkat tertentu dan dengan efek yang berbeda,merupakan tindakan perfomatif dalam bahasa, yaitu upaya menciptakan kenyataan melalui kata-kata dan bahasa. Kita juga sering mengenal salah satu model tindak tutur. Seorang hakim yang membacakan vonis tidak berbicara atas namanya sendiri, melainkan atas nama institusi hukum. Bagaimana efek yang ditimbulkan, kenapa bisa terjadi? Adalah pertanyaan yang patut diajukan dalam diskursus bahasa. Demikian juga pertanyaan yang juga patut diperhatikan. Berapa banyak kasus yang sebenarnya adalah berawal dari bahasa seperti pencemaran nama baik, pelecehan harga diri, fitnah, hasut dan lain-lain.

Sebuah pernyataan yang tidak disertai modal simbolik alih-alih membawa efek perfomatif yang diharapkan, bisa dicap sebagai "fitnah" dan berefek negatif pada penuturnya sendiri. Begitu pula,

6 Adeng Chaedar Alwasilah, Beberapa madhab dan dikotomi teori linguistike (Bandung: Penerbit Angkasa, 1993), 63.

7 S Zulkarnain, Perkembangan Kurikulum Bahasa Arab (Bengkulu: STAIN Bengkulu, 2007), 4. 
sebuah ceramah keagamaan tanpa modal simbolik bisa dikenali sebagai "hasutan". Ucapan-ucapan yang melanggar aturan, baik sosial maupun linguistik, bisa dianggap sebagai "tak tahu aturan", atau pada tingkat yang sangat parah akan dianggap sama sekali "tidak dimengerti" atau diacuhkan sebagai "omongan orang gila". Bagaimana agama memandang bahasa ? Bagaimana agama menjelaskan konsep bahasa?

Agama menggambarkan bahwa bahasa mampu menstruktur dunia karena ia terjalin erat dengan praktik-praktik non-bahasa. Bahasa dalam bentuk-bentuk simboliknya juga merupakan wilayah pertarungan, pergulatan dan dominasi, karena masing-masing kelompok akan berusaha mendefinisikan dunia sosial sesuai kepentingannya. Bahasa memediasi hubungan antara realitas material dunia sosial yang disebutnya "ruang sosial" dan dunia simbol dalam bahasa itu sendiri.

Dalam agama Islam menjelaskan secara implisit tentang konsep bahasa sebagaimana yang tercantum dalam Al-Qur'an. Ketika berbicara tentang bahasa, Islam mengaitkannya dengan beberapa hal, yakni berkaitan dengan kata, fakta, alat kekuasaan, bahasa dan hierarki sosial, bahasa dan alat kebohongan, alat bersumpah, pengingkaran kebenaran dan bahasa sebagai alat membuktikan kebenaran, Islam juga mengatur kaitan bahasa dengan etika (larangan menggunjing, fitnah, berkata buruk, berkata kotor dan lain sebagainyas)

Penilaian orang terhadap kehidupan beragama sering mempengaruhi gaya bahasa seseorang. Seperti gaya berbicara seorang santri ketika memahami atau membicarakan istilah-istilah dalam agama berbeda dengan orang-orang yang bukan santri. Orang dengan mudah mengklaim seseorang dalam identitas tertentu dengan melihat gaya bicara dan bahasa yang digunakan. Misalnya, jika seseorang fasih membaca Al-Qur'an maka otomatis muncul anggapan seorang tersebut berasal dari kultur kehidupan keluarga yang agamis.

Hubungan bahasa dan agama juga terlihat dalam masyarakat yang merasa keberatan jika kitab suci atau bacaan-bacaan dalam ritual 
ibadah keagamaan ditejermahkan dalam bahasa lain. Contohnya, orang Islam di masa silam keberatan terhadap penerjemahan AlQur'an. Bahkan sampai hari ini orang Islam pada umumnya menunaikan salat dengan bahasa Arab, bukan dalam bahasanya sendiri. Ada larangan keras menunaikan salat dengan bahasa Indonesia. Bahkan di sebagian besar masyarakat masih ditemukan fenomena unik terkait sikap masyarakat terhadap bahasa Arab. Misal, seorang takmir masjid mewajibkan khatib menyampaikan khotbah Jum'at dengan bahasa Arab walaupun khatib dan jamaah Jum'at sendiri tidak memahami apa yang disampaikan dan didengar.

Keluarbiasaan hubungan agama Islam dan bahasa Arab bagi masyarakat Indonesia sangatlah kuat. Hingga keluarbiasaan ini dapat direfleksikan dalam kesadaran transendental mereka. Melalui perasaan diri (self felling) ataupun berdasarkan pemahaman intelektual-rasionalmistiknya, secara psikologis sikap seseorang pembaca dan pendengar bahasa Al-Qur'an (Arab) yang walaupun tidak mengetahui arti dan makna mampu memberikan pengaruh terhadap sisi personalitasemosionalnya. Nyanyian arab yang vulgar, porno, bahkan berbau seks pun digemari oleh masyarakat Indonesia serta dianggap shalawat dan diputar dalam pengajian serta dianggap sesuai sunah Rasullullah SAW. Menurut mereka, mendengarnya mendapat pahala. Di pihak lain, mendengar, menirukan, dan menyanyikan lagu-lagu Barat yang berbahasa Inggris juga lagu-lagu ciptaan anak muda Indonesia dianggap bid'ah, kafir, melanggar etika dan nilai-nilai Islam meski mereka sama-sama tidak mengerti kandungan lagu tersebut. Bahkan, sebagian orang ketakutan melafalkan bahasa Arab dan Al-Qur'an dikarenakan adanya doktrin salah atau dosa (masuk neraka).

Bahasa Arab juga ditempatkan secara eksklusif pada kelas spiritual dan kelompok akademis (intelektual) serta kebudayaan tertentu, dalam status sosial budaya dan agama. Dahulu ada sebuah opini, para orang tua dan kiayi berbangga diri dan yakin akan dapat masuk surga jika memiliki anak yang pandai bahasa Arab dan mampu menghafal Al-Qur'an. Dahulu juga, seorang santri yang bisa membaca huruf Arab pegon dianggap sebagai anak yang cerdas dan soleh. 
Pernyataan diatas dapat menggambarkan bagaimana kuatnya hubungan antara agama dan bahasa dalam kehidupan masyarakat beragama. Namun, yang menjadi permasalahan terbesar di dalamnya sekarang adalah jika penggunaan bahasa dalam agama ini hanya dihafal tanpa pengertian dan penghayatan maknanya.

\section{Peran Bahasa Arab Dalam Masyarakat Muslim Pada Zaman Sekarang}

Bahasa Arab menjadi bahasa kitab suci dan tuntunan agama umat Islam sedunia, maka tentu saja ia merupakan bahasa yang paling besar signifikansinya bagi milyaran muslim sedunia, baik yang berkebangsaan Arab maupun bukan Arab9.

Karena sumber-sumber asli ajaran Islam dan ilmu-ilmu keislaman adalah bahasa Arab, maka sangatlah penting bagi umat islam terutama kalangan ilmuannya untuk mempelajari dan memahami serta menguasai bahasa Arab. Jika tidak sulit bagi kita untuk mengkaji Islam dari sumber aslinya yang berasal dari bahasa Arab.

Namun sayangnya bahasa Arab di Nusantara mengalami kemerosotan tajam ketika Belanda menjajah Indonesia. huruf Arab yang telah banyak digunakan oleh orang-orang Insonesia, diganti dengan oleh pemerintah kolonial Belanda dengan huruf latin. Usaha penghilangan pengaruh bahasa Arab dilakukannya secara sistematis, dengan mendirikan sekolah-sekolah seperti di Batavia, Pantai Utara, Makassar, Timor, Sumatera Barat, Cirebon dan banten. Kolonial Spanyol mendirikan sekolah Semianari di Solor Maluku dan Portugis mendiri sekolah yang lebih tinggi di Goa.

Tentu akibat dari perlakuan kolonial Belanda, Spanyol dan Portugis tersebut di atas, telah berakibat buruk bagi peran bahasa Arab di Indonesia, bahasa Arab semakin termarginalkan dalam pergaulan masyarakat Indonesia, yang akhirnya terkerangkeng dalam pesantren-pesantren. Nasri Syukur menjelaskan bahwa pemerintah kolonial berperan penting dalam kemunduran pengaruh bahasa Arab

9 Azhar Arsyad and Nurcholish Majid, Bahasa Arab dan metode pengajarannya beberapa pokok pikiran (Yogyakarta: Pustaka Pelajar, 2010), 14. 
di Indonesia, yang hanya dipelajari di pondok-pondok pesantren secara eksklusif, dalam artian tidak dipelajari secara utuh sebagai alat komunikasi, melainkan bahwa bahasa Arab hanya layak dipelajari oleh "kaum sarungan" di pesantren dan tidak layak dipelajari oleh kaum priyayi di sekolah10.

Sungguh menyedihkan apa yang menimpa kaum muslimin saat ini. Hanya segelintir dari mereka yang mau mempelajari bahasa Arab dengan serius. Ini sangat wajar, karena di zaman modern ini banyak kaum muslimin tenggelam dalam tujuan dunia yang serba materialistik, praktis dan instan. Mereka enggan mempelajari bahasa Arab. Mereka tahu, tidak cukup terlihat nyata adanya hasil duniawi yang bisa diharapkan jika pandai berbahasa Arab. Berbeda dengan mempelajari bahasa Inggris, Jepang, dan Mandarin. Mereka sadar, banyak tujuan duniawi yang bisa diperoleh jika pandai bahasa-bahasa tersebut.

Bahasa selain bahasa Arab, seperti bahasa Inggris, Mandarin, Jepang dan yang lainnya bersangkut paut dengan kebutuhan ekonomi. Misalnya, untuk kepentingan bisnis dan tenaga kerja. Kita dapati mereka rela meluangkan waktu yang lama dan biaya besar untuk bisa menguasai bahasa ini. Bagi sebagian besar masyarakat, menguasai bahasa Inggris, Mandarin, Jepang, dan yang lainnya akan memberikan kesuksesan masa depan. Anggapan sebagian besar masyarakat terhadap bahasa Arab adalah bahwa semangat mempelajari bahasa Arab adalah sebatas sebagai sarana memahami agama dalam kerangka motivasi ibadah. Dengan bahasa Arab, maka mereka mampu memahami bacaan salat dan membaca kitab-kitab ajaran agama (AlQur'an dan hadis).

\section{Verbalisme Dalam Agama Masyarakat Muslim}

Secara struktural dan fungsional, cermin pengalaman agama masyarakat Jawa-Indonesia yang menjadikan fungsi dan subtansi nilai agama selalu kabur, kehilangan vitalitas dan fungsinya, adalah akibat adanya praktik verbalisme. Verbalisme berasal dari kata verba, yang

10 Ahmad Fuad Effendi, 'Peta Pelajaran Bahasa Arab Di Indonesia', Jurnal Bahasa Dan Seni, n.d., 407. 
memiliki arti amaliah secara lahir (gerak lahir semata), hampir searti dengan formalitas, sekedar bentuk. Praktik verbalisme dalam kriterium ini adalah tidak adanya suatu nilai batiniah.

Verbalisme juga dapat dipergunakan untuk menyebut tulisan atau uraian yang mempergunakan terlalu banyak kata, sedang isinya terlalu sedikit, tanpa isi atau terlalu sedikit, atau sama sekali tak menyentuh topik yang sedang dibicarakan, alias omong kosong. Penganut verbalisme memperlakukan kata lebih penting daripada kenyataan yang diungkapkan. Secara umum verbalisme dapat menjadikan kata, ungkapan, ucapan, sebagai hal atau entitas yang berdiri sendiri. Dalam dan dengan anggapan itu, orang sudah dianggap baik, loyal, terhormat, hanya karena kata-katanya yang bernada sedap, mendukung dan menyanjung, tanpa menyelidiki bagaimana perilaku yang sesungguhnya. Sebaliknya orang seringkali dianggap jahat dan pengacau, hanya karena ucapan-ucapannya yang terus terang, berbeda dengan yang lazim dan kritis, meskipun perbuatan nyatanya sungguh membawa kebaikan bagi banyak orang11.

Verbalisme telah terjadi dalam masyarakat muslim di Indonesia. Di antaranya adalah doa dan dzikir yang menggunakan bahasa Arab hanya dihafal tanpa pengertian dan penghayatan maknanya. Misalnya juga khotbah dengan bahasa Arab umum yang tidak mungkin dipahami maksudnya, membaca doa berbahasa Arab tetapi tidak tahu maknanya, melafalkan bacaan dalam gerakan salat tetapi tidak tahu maknanya, rutin membaca dan mendengarkan bacaan ayat suci $\mathrm{Al}$ Qur'an tetapi tidak pernah memahami arti dan maksudnya.

Untuk dapat memahami isi kandungan al-Qur'an dengan baik dan benar, menurut Doktor A'isyah Abdurahman atau yang biasa dikenal dengan "Bintusy Syathi" paling tidak dibutuhkan kemampuan dalam memahami mufradat (kosakata) al-Qur'an dan uslub (gaya bahasa)-nya, dengan pemahaman yang bertumpu pada kajian metodologis-induktif dan menelusuri rahasia-rahasia ungkapannya. Issa J. Boullata dalam kata pengantarnya terhadap buku tafsir Bintusy-

11 A Mangunhardjana, Isme-isme dari A sampai Z (Yogyakarta: Kanisius, 1997), 232-36. 
Syathi' menjelaskan bahwa, dalam mengkaji al-Qur'an Bintusy-Syathi' menggunakan empat butir metode yang salah satunya disebutkan, “ karena bahasa Arab adalah bahasa yang digunakan dalam al-Qur'an, maka untuk memahami arti kata-kata yang termuat dalam kitab suci itu harus dicari arti linguistik aslinya yang memilki rasa keakraban kata tersebut dalam berbagai penggunaan material dan figuratifnya12".

Penelitian 13 menghadirkan pemahaman bahwa bahasa arab mempunyai keistimewaan bukan hanya karena bahasa yang dibawa agama islam. Akan tetapi bahasa arab mempunyai hal yang unik untuk dikaji daripada bahasa yang lain. Dengan mengkaji kembali beberapa keunikan yang ada lama bahasa arab maka kita akan merasakan keistimewaan dalam bahasa al-Qur'an. Dan kita akan mendapatkan alas an kenapa al-Qur'an diturunkan dengan menggunakan bahasa arab

Harus diakui, kebanyakan umat Islam hari ini bisa dikatakan terbelakang dan jumud karena mereka tidak menguasai bahasa Arab. Ini diketahui ketika pelakukan penerjemahan teks-teks bahasa Arab, terkadang seorang penerjemah dihadapkan pada berbagai kesulitan yang berkaitan dengan aspek kebahasaan, non kebahasaan dan kebudayaan 14

Sehingga menyebabkan mereka kurang mengetahui dan menghayati arti agama, termasuk ibadah, ritus-ritus dan fungsi agama itu sendiri. Kehadiran mereka pada majelis taklim dengan begitu rajin, umpamanya, atau dalam menjalankan salat serta melaksanakan ritusritus lain, tak lebih dari realitas ordiner semata. Atau lebih banyak didorong oleh tuntutan lingkungan sosial, karena pakewnh, mengharap simpati, atau menghilangkan rasa enggan di masyarakat.

Kenyataan ini bisa kita lihat sampai sekarang. Sembahyang orang muslim ada yang hanya sekali dalam satu minggu (salat Jum'at),

12 Badri Khaeruman, Islam Ideologis: Perspektif Pemikiran Dan Peran Pembaruan Persis, Cet. 1 (Jakarta: Misaka Galiza, 2005), 19.

13 Hasyim Asy'ari, 'Keistimewaan Bahasa Arab Sebagai Bahasa Al-Qur'an', Nidhomul Haq: Jurnal Manajemen Pendidikan Islam 1, no. 1 (2016): 25, https://doi.org/10.31538/ndh.v1i1.5.

14 Syihabuddin, Penerjemah Arab-Indonesia 'Teori-Praktik' (Bandung: Humaniora, 2005), 149. 
atau dua kali dalam setahun (salat Idul Fitri dan Idul Adha), mereka membaca Al-Qur'an setiap hari, tetapi tidak berupaya mengetahui maknanya. Ada pula opini yang dibangun di masyarakat "jangan sekali-kali mati kecuali dalam keadaaan beragama Islam", "Jangan sampai kita mati dalam keadaan tidak membaca syahadat, sebab ini kunci orang Islam". Itulah bukti bahwa Islam menurut kebanyakan dari kita hanyalah lahiriah dan formalitas semata.

Selain itu, pokok persoalan dalam pergumulan masyarakat terhadap teks-teks dan ajaran agama adalah bahwa sebagian besar masyarakat dan generasi sekarang cenderung membaca dan memahami teks keagamaan klasik sebagai produk final yang siap dipakai, siap dilaksanakan begitu saja dalam kehidupan sehari-hari. Mereka tidak merasa perlu mempertimbangkan latar belakang dan historisitas munculnya ide-ide, konsep, hukum-hukum, dan sejenisnya yang termuat dalam teks-teks agama yang diyakini termasuk teks-teks berbahasa Arab bagi umat Islam seperti Al-Qur'an dan hadis. Kondisi tersebut mengakibatkan pemikiran keislaman sulit berkembang bahkan kehilangan relevansi ketika berhadapan dengan arus gelombang tantangan zaman yang membutuhkan ijtihad-ijtihad baru. Ini diperparah dengan kondisi pergumulan masyarakat dengan teksteks berbahasa Arab yang lebih terjebak dalam mitologisasi, menganggap semua wilayah agama bersifat sakral, normatif. Mereka tidak mampu memasuki wilayah untuk pemahaman dialogis-kritis.

Ini problem masyarakat Islam. Selain porsi bahasa Arab dalam pembelajaran yang dimiliki jauh lebih sedikit dibandingkan bahasa dan mata pelajaran lain, juga karena tidak adanya sikap ataupun pembongkaran terhadap pemahaman yang kaku terhadap agama dan teks.

Jika saja mereka mau belajar bahasa Arab dari aneka sumber, maka itu bisa memberikan berbagai keuntungan di dalamnya, yaitu di antaranya akan menimbulkan pemahaman yang mendalam dalam pembelajaran bahasa Arab itu sendiri, selain itu juga bisa meningkatkan pembentukan ketrampilan berpikir seperti ketampilan memecahkan masalah, memberikan pertimbangan-pertimbangan dan 
melakukan evaluasi melalui penggunaan informasi dan penelitian secara mandiri15.

Namun, kecenderungan masyarakat muslim Indonesia dalam mempelajari bahasa Arab (bahasa Al-Qur'an dan hadis) yang cukup besar hanya terbatas sebagai prosedur formal. Bahasa Arab bagi sebagian besar masyarakat muslim Indonesia masih dekat di mata jauh di hati.

\section{Aktivitas Verbalis Dalam Pembelajaran Bahasa Arab}

Sebuah salah kaprah jika pengetahuan agama hanya wajib di hafal tanpa memperhatikan kadar ilmiah dan nilai batiniah serta sisi mentalitasnya. Hal tersebut akan berefek tidak menguntungkan. Verbalisme dan kelemahan pengetahuan dalam bahasa Arab merupkan kendala dan tantangan dalam reformasi kehidupan beragama. Fenomena ini sangat mudah kita jumpai saat ini. Hampir di seluruh masyarakat Jawa kita temukan sekian aktivitas yang hanya menekan pada pengetahuan yang verbalis seperti yasinan, diba'an, dan istighasah tanpa disertai kajian kritis-analitis atas apa yang dikerjakan.

Ditambah dengan problematika waktu belajar di madrasah yang terbatas, juga dengan jumlah siswa dalam setiap kelas yang kadang tidak menggunakan jumlah minimum, sementara jumlah mata pelajaran yang juga tidak sedikit. Semuanya menjadi rangkaian yang membentuk masalah tersendiri sehingga tidak dapat menemukan keberhasilan pembelajaran bahasa Arab, ini menjadikan pengajaran bahasa Arab hanya sekedar menjadi formalitas belaka dan pengetahuan yang diajarkan hanya terbatas pada pengajaran verbalis 16 .

Opini yang terbangun di masyarakat adalah bahwa belajar bahasa Arab adalah belajar kesia-siaan. Sekarang sudah banyak ulama, sudah banyak buku-buku yang mengkaji Islam sehingga kita tidak perlu susah-susah belajar dan mempelajari bahasa Arab. Cukup para ustaz, kiai, dan orang-orang tertentu saja yang belajar bahasa Arab.

15 Dewi Padmo, ed., Teknologi Pembelajaran: Upaya Peningkatan Kualitas Dan Produktivitas Sumber Daya Manusia, Ed. 1 (Ciputat, Tangerang: Universitas Terbuka, 2003), 42.

16 Azhar Arsyad and Nurcholish Majid, Pembelajaran Bahasa Arab di Madrasah. (Yogyakarta: Depublish, Publiser, 2016), 205. 
Situasi yang demikian diperpuruk dengan anggapan bahwa belajar bahasa Arab adalah tidak penting. Kelak di surga kita sudah bisa berbahasa Arab dengan sendirinya, karena bahasa penduduk surga adalah bahasa Arab. Bahasa Arab hanya layak dipelajari oleh para santri.

Di satu sisi, saat ini memang tidak susah menemukan anak kecil yang mampu membaca Al-Qur'an dan tulisan-tulisan. Sayangnya, sebagian besar dari mereka belajar bahasa Arab dan Al-Qur'an sampai usia dan jenjang tertentu saja. Jika sudah mampu membaca tulisan berbahasa Arab, salah satunya Al-Qur'an, maka selesailah tugas belajar agama. Kesuksesan hanya diukur oleh mampu membaca sampai 30 juz yang dilakukan secara rutin setiap hari, bukan pada proses pemahaman terhadap isi dan kandungannya. Budaya membaca AlQur'an hanya ritual membaca dan menghafal, belum masuk pada proses tafahbum, tadabbur, ta'aaqul, dan yang lainnya.

\section{Dampak Negatif Verbalisme Bahasa Arab Pada Kehidupan Beragama Masyarakat Muslim}

Bahasa berkaitan erat dengan adat, budaya, dan lingkungan sosialnya. Keterkaitan ini menimbulkan beragam makna yang sulit ditemukan padanannya dalam bahasa sasaran, karena perbedaan kultur sosial dan budaya antara dua bahasa (Mujadi: tt. 106). Dengan itu maka pentinglah pembelajaran bahasa Arab yang tidak hanya sebatas formalitas secara verbalis saja untuk bisa memahaminya dengan baik. Karena verbalisme dalam bahasa Arab bisa memberikan dampak negatif pada masyarakat muslim sendiri, beberapa contoh darinya yaitu: 17

Pertama, penarikan kesimpulan yang salah dari dalil-dalil agama, misalnya dalil-dalil dalam Al-Qur'an dan hadis. Banyak dai yang fasih mengutip dalil dari ayat suci, hadis serta pendapat ulama, tetapi justru sering menimbulkan konflik, tuding-menuding, curiga, dan fitnah anatar pemeluk agama. Dalil-dalil Al-Qur'an dipaksakan untuk menjelaskan materi-materi ceramah tanpa mengetahui aspek-aspek 
dalam dalil itu sendiri. Ayat-ayat Al-Qur'an akhirnya salah dipahami oleh pendengar.

Kedua,sikap keras yang berlebihan oleh pemeluk agama. Agama diturunkan bukan untuk memberatkan pemeluknya, tetapi justru memberikan keringanan kepada pemeluknya. Jika seseorang tidak cermat memahami latar belakang teks-teks sejarah agama dan terlalu keras menjadi ulama, pada akhirnya mereka bebas menafsirkan ayatayat untuk kepentingan yang dianggapnya benar oleh dirinya dan anggota-anggotanya.

Ketiga, taklid ketidaktahuan masyarakat terhadap bahasa Arab dan ajaran-ajaran agama akhirnya membawa mereka menjadi muqalid. Artinya, adalah menjadi pengikut-pengikut yang tidak tahu menahu dan asal mengikuti pendapat orang banyak. Allah berfirman:

'Dan apabila dikatakan kepada mereka, Tkutilah apa yang telah diturunkan Allab', mereka menjawab, '(Tidak), tetapi kami hanya mengikuti apa yang telah kami dapati dari (perbuatan) nenek, moyang kami'. '(Apakah mereka akan mengikuti juga),walaupun nenek moyang mereka itu tidak mengetahui suatu apapun, dan tidak mendapat petunjuk?!" (Q.S. Al-Baqarah: 170).

\section{Kesimpulan}

Kehidupan beragama yang belakangan ini kita rasakan seolah mengalami kemandekan (stagnasi). Ilmu agama seolah terbelakang dibandingkan dengan perkembangan bangunan keilmuan yang lain. Jika dianalisa memang sebabnya, kita melihat ada kaitan erat dengan praktik verbalisme dan ketidakmampuan dalam penguasaan bahasa Arab yang sudah demikian lama berkarat dan membudaya di masyarakat.

Inilah yang kerap kali menjadi problem khusus dalam masyarakat Islam. Akibat tidak memahami bahasa Arab, akhirnya agama mudah dijual, agama mudah diselewengkan, agama dibawa oleh oknum pada jalan penyimpangan, agama dijadikan alat untuk kepentingan dan tujuan-tujuan tertentu. Selain itu, pemahaman masyarakat terhadap agama menjadi tidak sempurna. Umat Islam tidak mengerti dan jarang mampu meneliti secara menyeluruh 
masalah-masalah yang sebenarnya bersangkut paut dengan teks-teks ajaran agama. Akhirnya, agama menjadi larut dalam masalah-masalah tertentu, agama menjadi rusak, dan

Oleh karenanya, secara umum diperlukan upaya perombakan dalam sebuah ideologi yang salah, termasuk mengubah budaya verbalisme dalam masyarakat.

Bukan suatu hal mustahil perkembangan keagamaan masyarakat Indonesia menjadi lebih baik jika ada upaya untuk kembali menempatkan posisi bahasa Arab tidak saja untuk dihafal tetapi digunakan sebagai alat dalam mendalami ilmu pengetahuan, salah satunya ilmu agama.

\section{Referensi}

Abdul Gaffar Hamid, Hilal. Ilmu Lughah Bainal-Qadim wal-Hadist.

Cairo: Dar al-Kotob Al-Ilmiyah, 1986.

Alwasilah, Adeng Chaedar. Beberapa madhab dan dikotomi teori linguistik.

Bandung: Penerbit Angkasa, 1993.

Aminuddin. Pengantar Studi Tentang Makna. Bandung: Sinar Baru, 1988. Arsyad, Azhar, and Nurcholish Majid. Bahasa Arab dan metode pengajarannya beberapa pokok pikiran. Yogyakarta: Pustaka Pelajar, 2010.

C. Pembelajaran Babasa Arab di Madrasah. Yogyakarta: Depublish, Publiser, 2016.

Asy'ari, Hasyim. 'Keistimewaan Bahasa Arab Sebagai Bahasa AlQur'an'. Nidhomul Haq: Jurnal Manajemen Pendidikan Islam 1, no. 1 (25 March 2016): 21-28.

Effendi, Ahmad Fuad. 'Peta Pelajaran Bahasa Arab Di Indonesia',. Jurnal Bahasa Dan Seni, n.d.

Keraf, Gorys. Komposisi: sebuah pengantar kemahiran bahasa. Ende, Flores: Nusa Indah, 2001. http://catalog.hathitrust.org/api/volumes/oclc/66969327.ht $\mathrm{ml}$.

Khaeruman, Badri. Islam Ideologis: Perspektif Pemikiran Dan Peran Pembaruan Persis. Cet. 1. Jakarta: Misaka Galiza, 2005. 
Mangunhardjana, A. Isme-isme dari A sampai Z. Yogyakarta: Kanisius, 1997.

Manna, Al-Qattan. Mababis Fi 'Ulumi-Qur'an. 4th ed. Riyad: Mansyurat al-Asr al-Hadis, 2005.

Mujib, Fathul. 'Rekonstruksi Pendidikan Bahasa Arab'. Yogyakarta: Pedagogia, 2010.

Padmo, Dewi, ed. Teknologi Pembelajaran: Upaya Peningkatan Kualitas Dan Produktivitas Sumber Daya Manusia. Ed. 1. Ciputat, Tangerang: Universitas Terbuka, 2003.

S Zulkarnain. Perkembangan Kurikulum Bahasa Arab. Bengkulu: STAIN Bengkulu, 2007.

Syihabuddin. Penerjemah Arab-Indonesia 'Teori-Praktik'. Bandung: Humaniora, 2005. 